

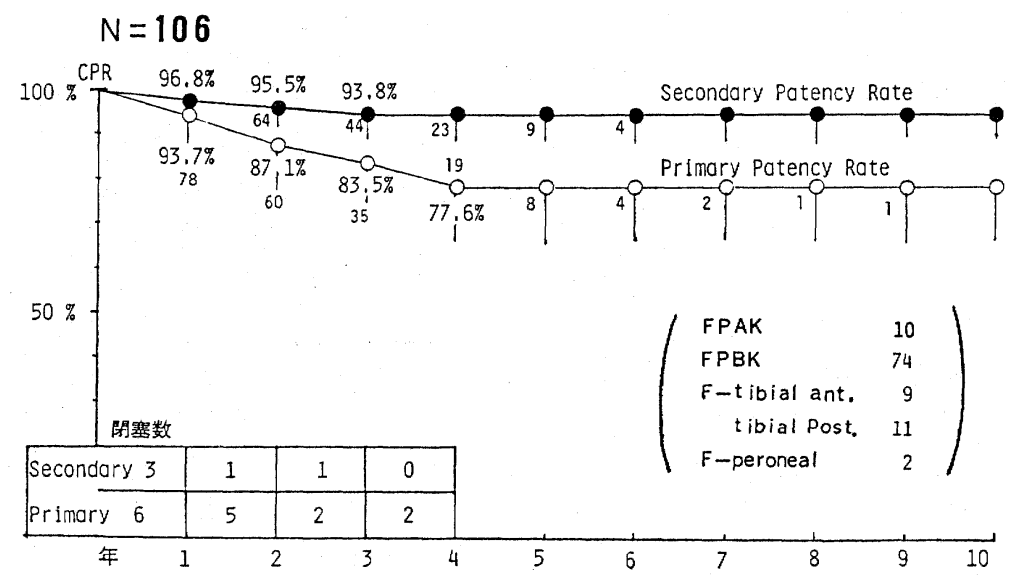

図 1 下肢末梢 ASO 亿対する reversed vein bypass 累積開存率

察 10 年で 106 肢中 9 肢に中間期（術後 3 力月〜 2 年）に おりる graft 狭窄, 閉塞および晚期病変進行が発生し, 10 肢で種々の形の graft salvage 手術に成功した. 最終 的な graft 閉塞は 5 肢である. 10 肢の salvage 成功例 を開存として取り报う secondary patency rate (SPR) は 10 年まで $93.8 \%$ でる(図 1 ). 一方, 10 肢を salvage 手術の時点で閉塞と見なした場合の primary patency rate (PPR) は $77.6 \%$ であった. 開存率は術 式では差がなく, PPR と SPR の 16\% の差は厳重な follow up による graft salvage の賜物である. ISVB は最長観察 29 力月で, 46 例中 9 例で中間期の graft 内膜肥厚 (IH) による狭窄が発生したが，6 例は salvage に成功し, 最終的に 3 例が閉塞となった. ISVB とRVB は開存率, IH 発生率とあ差がみられなかった. そこで AVG の主要な閉塞原因である IH について AVG の 良否（表 1) とその発生率を検討した。 これによると poor 群で $52.6 \%$ に IH による狭窄, 閉塞が発生し, good および fair 群とは明らかな差を示した $(p<0.005)$

表 1 自家静脈 graft の良否判定之抗凝血療法 (AC) の必 要度および graft 内膜肥厚 (IH) 発生の可能性

\begin{tabular}{|c|c|c|c|}
\hline \multirow{2}{*}{ 内 } & \multicolumn{3}{|c|}{ 拡 張 性 } \\
\hline & 良 & 好 & 不 良 \\
\hline $4 \mathrm{~mm}$ 以上 & Good & $\begin{array}{l}\text { AC }(-) \\
\text { IH }(-)\end{array}$ & $\begin{array}{lll}\text { Poor } & \text { AC }(H) \\
& \text { IH }(H)\end{array}$ \\
\hline $3 \sim 4 \mathrm{~mm}$ & Fair & $\begin{array}{l}\mathrm{AC}(+) \\
\mathrm{IH}( \pm)\end{array}$ & 使用禁止 \\
\hline$<3 \mathrm{~mm}$ & Poor & $\begin{array}{l}\mathrm{AC}(+) \\
\mathrm{IH}(+)\end{array}$ & 使用禁止 \\
\hline
\end{tabular}

拡張性および内径：graft の 加圧処理時 (後). Good：IH の可能性なく $\mathrm{AC}$ 不要. Poor: IH 必発, AC 必須.
(図 2). 以上の結果から AVG の良否こそが AVB の 開存率と密接に関係しているといえる.下肢 ASO に 対する DB の成績は各術式亡も最長観察 9 12 年とな っている. そのなかで FP bypass 50 例の CPR は， 5 年 $64.7 \%, 6 \sim 10$ 年まで $56.7 \%$ で，その主要な閉 塞原因は吻合部内膜肥厚 $(\mathrm{AIH})$ であった。骨盤型 $\mathrm{TAO}$ は 24 肢中 6 肢閉塞で, 全体の開存率は $75 \%$ である. 使用代用血管は e-PTFE 9, VKD 12，DB 1，AVG 2 であるが開存率は材料による差がみられなかった．閉塞 5 graft (3 例) はいずれあ喫煙継続例であった，下肢 末梢 $\mathrm{TAO} 43$ 例では最長観察 10 年で 11 例が閉塞し た. 閉塞原因は graft 不良 3 , technical error 2 , 病 変進行 6 で, 病変進行はいずれも喫煙継続または再開例 であり，契煙が ASO に比べより直接的に bypass 手 術成績を悪化させる要因と考えられた. CPR は 1 年 $85.7 \% ， 4 \sim 10$ 年 $69.7 \%$ であった. 下肢多発生動脈閉 塞に対する $\mathrm{SqB}$ は最長観察が 5 年にみたないが, AVG 15 例に全閉塞はない。分節的 graft 閉塞は中枢側 1 ,

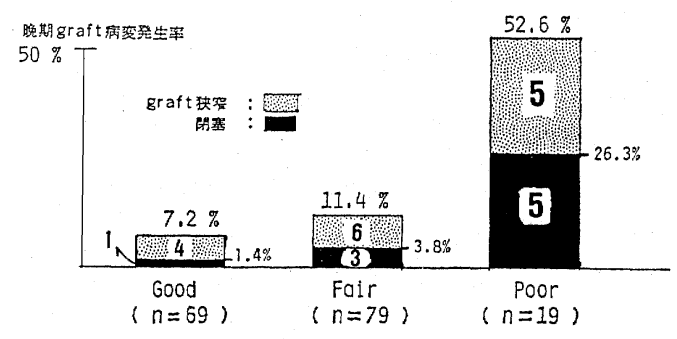

図 2 下肢末梢 ASO 亿対する自家静脈 bypass graft の 良否亡 IH による晚期狭窄, 閉塞発生率 動脈硬化性病変進行による狭寉, 閉塞例は除いてある. 表 1 の判定による poor 群で高率に IH の発生がみられる. 
中間 1 , 末梢側 3 であり, 閉塞原因は graft 不良 2 , 病 変進行 2 , 不明 1 であった. 足関節以下への bypass は, AVG では 18 例中 7 例閉塞, 開存率 $61.1 \%$, 救 肢率 $83.3 \%$ で，乙のレベルの再建では満足すべき結果 と考えられた。

\section{考 察}

慢性下肢動脈閉塞症に対する血行再建では動脈瘤の場 合と異なり再建後の血流量は閉塞病変の拡がりと程度に より大きく異なるととから，使用代用血管の選択に当た ってはそれに関する十分な知識が必要である. Ao-F で は Dacron 織布人工血管の使用に異論のないところであ るが，われわれは Ao-F において WD と VKD の開 存性の差をみるため, あえて WD 26 本を移植し最長 7 年まで観察しているが，両者に差はみられなかった。し かし再手術や剖検剔出標本により観察された器質化状況 はVKD では run-off 良好例や適切な down stream repair (DSR) により十分な graft 血流量が与えられた 例では比較的良好な内包層形成が確認された. VKD で あ graft 口径が過大な例 $(10 \mathrm{~mm})$ P run-off 血管が 不良な深大腿動脈のみの例では吻合部 Pannus のみで graft 中央部の器質化はみられなかった。このような器 質化の相違は，人工血管の有孔度のほかに血流に見合っ た至適な口径の選択が重要であるととを示している.し たがって通常 Ao-F では直管なら $8 \mathrm{~mm}$ (Y型なら 16 $\times 8 \mathrm{~mm}$ または $14 \times 8 \mathrm{~mm})$ VKD でよいが，良好な器 質化を期待するならば十分な DSR が必須であり，それ が不可能な症例ではより小口径とするか $\mathrm{DB}$ などに変 更するしかない. その点 extraanatomic bypass では器 質化を考慮した代用血管の選択は，生存率から考えて意 味がない. Ax-F では Ao-F ほど血流量が得られないこ とが多いため血液適合性の高い代用血管を選択すべきで ある. 代用血管は $8 \mathrm{~mm}$ 補強 e-PTFE を第一選択とし， 病変が高度で DSR が不十分な例では $6 \mathrm{~mm} \mathrm{DB}$ また は e-PTFE の使用を考慮すべきである.

大腿以下の再建では疾患, 術式に関係なく自家静脈が 第一選択である.AVG の移植法に関しては最近 ISVB の FP bypass 3 年 $85 \%$, F-Tib. $87 \%$ と良好な成績 が報告されている11. しかしわれわれの RVB の成績は SPR 93.8\%，PPR 83.5\% とそれらに十分匹敵するも のである．また中間期における IH 発生率も RVB 11.3 \%, ISVB $15.2 \%$ で両者隹有意差はみられない. 以上 より AVB の成績に関与する因子として AVG の良否 が，まず第一に重要であり（図 $2 ， 3$ ), RVB か ISVB
かあるいは non-reverse かといったととは本質的な 問題ではないと考えられる. Graft の IH は術後 3〜24 カ月に好発するため，乙の間は血管雑音周波数解析 ${ }^{2)}$ graft 血流波形解析 ${ }^{32}$ による 1 〜 カ月どとの follow up を徹底し, 可能な限り抗凝血療法を行うべきであ る. AVG は大伏在静脈を第一選択とし，上腕尺側皮静 脈 $(6 \mathrm{~mm}, 15 \mathrm{~cm})$, 小伏在静脈 $(3 \mathrm{~mm}, 20 \mathrm{~cm})$, 梁大腿 静脈 $(6 \mathrm{~mm}, 6 \mathrm{~cm})$ などの順に選択し，不良な部分は捨 てて composite とするととに躊躇すべきでない，橈側 皮静脈や外頸静脈は壁が薄く, 縫合手技上および耐圧性 に問題があるのでできるだけ使用を避けるべきである.

TAO に対する bypass 手術では骨盤型, 末梢型とも 契煙が開存に值接関与していると考えられた。したがっ て bypass 術後の禁煙厳守を前提に手術を行うべきであ る. この場合，職場なごでの間接喫煙にも注意を払う必 要がある.TAO bypass 手術例における喫煙による病 変進行は吻合部を中心に宿主血管を含めて $2 \sim 3 \mathrm{~cm}$ の 範囲で限局性閉塞像を示すのが特徵である．遠隔では喫 煙がない限り病変進行はみられず成績は ASO よりもむ むしろ良好である。

DB は FPBK までに限っても AVG とは 5 年 $\mathrm{CPR}$ で $20 \%$ 以の差がみられる. AIH が主要な閉塞原因で あるが，その salvage 手術は中枢吻合部は容易である が，発生率の高い末梢吻合部ではまったく成功例がな い. この AIH が解決しない限り AVG の成績に近づ くことは不可能であり, 今後小口径人工血管開発におけ る最重要課題と考えられる.

下肢末梢多発性動脈閉塞に対し bypass 手術を考える 場合, 再建対象動脈の決定に迷う場合が少なくない. 多 発病変は糖尿病を伴う ASO に多くみられ，病変進行が 早い特徴がある. これに対し $\mathrm{SqB}$ の目指すところは bypass 術後の病変進行による graft 閉塞の防止と徹底 した血行改善であり，たとえ病変進行があってあ graft が全閉塞にいたることがなく limb salvage に役立つむ のと考えられる. SqB は単一 bypass よりも有意に graft 血流量が多いことからあその有效性が裏づけられ た.

足関節以下への by pass は足関節レベルで主幹 3 動脈 に閉塞病変がある足趾潰瘍, 壊死例に対する salvage が 目的である. 対象は TAOの 急性増悪や糖㽷病が多く, 腰部交感神経節切除が無効な例が少なくない. 再建対象 動脈は足背動脈, 総足底動脈および拇趾外転筇下の内, 外側足底動脈までである. 中枢吻合は膝下位膝窩動脈之 し, 下腿の大伏在静脈 (内径 $3 \mathrm{~mm}$ ) を reverse 移植す 
るのがよい，

\section{結論}

慢性下肢動脈閉塞症に対する bypass 手術における代 用血管の選択について, 10 年間の遠隔成績加ら以下の 結論を得た.

1) Ao-F では VKD $8 \mathrm{~mm}$ ( $\mathrm{Y}$ 型ならば $16 \times 8$ ，ま たは $14 \times 8 \mathrm{~mm}$ ) を使用する. Ax-F, F-F では $8 \mathrm{~mm} の$ 補強 e-PTFE を使用する。 乙の場合, 大腿動脈末梢の run-off が不良ならば積極的な DSR が大切であるが, 不可能ならば $6 \mathrm{~mm} \mathrm{DB}$ または e-PTFE を選択する.

2）下肢末梢動脈再建では AVG が第一選択である が，graft 良否に注意し，不良部分は躊踫なく切除し composite graft とする. 移植後 2 年間は graft IH に 注意し 3 カ月ごと follow up する. その間抗凝血療法 を継続する.

3） AVG 次ぐ第二選択代用血管として DB（およ び e-PTFE) は FPBK までを適用限界とする. AIH は終生，収束停止するととがないので抗凝血療法を可能 なかきり長期継続すべきである.

文 献 1) Fogle, M. A. et al.: J. Vasc. Surg. 5: 46, 1987. 2) 笹嶋唯博は加：第 5 回血管に関する無侵襲診断法研 究会抄録集，43-44，1985. 3) 吉田博希ほか：第6回血管に関 する無侵襲診断法研究会抄録集, 33-34, 1986.

\title{
S-III-3 末梢動脈閉塞症に対する血行再建術の成績と問題点
}

\author{
名古屋大学 第 1 外科, 愛知医科大学 第 2 外科* \\ 桜井恒久塩野谷恵彦太田敬*
}

下肢血行再建術の術後経過の評価にグラフトの開存が 重要な指標であるととは当然であるが，それと同時に血 行再建術を受けた患者が術後どのような日常および社会 生活を送っているかを追跡調查することは患者の quality of life を評価する上で重要なととと思われる.

今回，われわれは血行再建術を受け，5年以上経過し た患者の手術成績を報告するとともに，患者の健康状態 および社会生活において重要な意味をもつ術後の就労状 況についても調查, 解析を行ったのでその結果について あ報告する. そして, 現在われわれの閉塞性動脈硬化症 (以下, ASO と略) とバージャ一病 (以下, TAO と 略）の各疾患に対する血行再建術の手術適応について述 べる.

\section{対象と方法}

名古屋大学分院外科にて血行再建術を受け術後 5 年以 上経過した 124 名の症例を対象とした. 原疾患は ASO が 81 名, TAO が 43 名であった. 性別は ASO K 女子 13 名を認めたが, TAO は全例男子であった. 症 例の手術時の平均年齢は ASO が 61 歳, TAO が 41.3 歳と有意に ASO 群が高㱓であった.

術前の症状では, ASO 群に Fontaine II度の間欠性
跛行症例が 51 例と多いのに対し, TAO 群には Fon taine III, N 度の安静時痛または虚血性潰瘍を呈するい わゆる foot salvage を必要とする症例が 27 例と有意 に多かった．血行再建部位として anatomic bypass を 骨盤領域，大腿領域，下腿領域に分け， extraanatomic bypass は別化分類した. その結果，ASO 群はおのおの 26, 26, 11，18 例であり, 一方, TAO 群は 13, 3, 26，1例であった．ASO 群に骨盤および大腿領域の血 行再建術が多いのに対し, TAO 群では有意に下腿領域 の血行再建術が多かった. また, extraanatomic bypass は 1 例を除き，全例が ASO 症例であった。

グラフト開存の観察期間はわれわれによって確認され た最終彮察日までとし, それ以降は脱落とした.

各症例飞対して, 面接法执よびアンケート法にて, 術後 の健康状態㧍よび下肢の症状を調査した. この方法にて ASO 68 例, TAO 41 例の計 109 症例の日常生活の状 態を確認し得た. そして, 術後の就労状況は術前に就労 していた男子患者のみを対象とし, ASO 38 例, TAO 34 例の計 72 例から回答を得た.

今回のわれわれの報告においては，まず血行再建部位 別の手術成績を呈示し, ついで, 疾患別にその累積開存 率の特徴を検討した。 ついで, 疾患別优後の健康状態 